\title{
Konsep Model Formulasi Rasio Kebutuhan Bahan Perpustakaan (Analisis Kuantitatif Kebutuhan Bahan perpustakaan Sekolah Tinggi Agama Islam Negeri Curup Tahun 2017)
}

\author{
Misroni $^{1}$, Rahmat Iswanto ${ }^{2}$ \\ ${ }^{1}$ Universitas Islam Negeri Raden Fatah Palembang \\ ${ }^{2}$ Perpustakaan Sekolah Tinggi Agama Islam Negeri Curup \\ 1e-mail: misroni_uin@ radenfatah.ac.id \\ ${ }^{2}$ e-mail: rahmatiswanto.database@gmail.com
}

\begin{abstract}
This article is a concept that aims to answer some problems. They are what factors determine the library users' needs, how to formulate the ratio of the needs, how the formulation of the ratio of the needs for users of the State Islamic University of Curup and how the collection deviates from the needs. The type of this research is descriptive analysis research. The population of this research is the civitas academic of State Islamic University of Curup in 2017. The process of analysis is done by laying down descriptive concepts so that it could create a formula that can be used to measure the needs of library materials. The minimum amount of library material for the State Islamic University of Curup is 38,516 titles. The deviation occur because of collections damage, collection losses, out-of-date collections, the addition of the number of users, the development of university, and the lending to college employees who are not counted as library's users. The Library of the State Islamic University of Curup still need to communicate well to its users so that what they need can be recorded and fulfilled by the library.
\end{abstract}

Keywords: Pengembangan koleksi; Koleksi perpustakaan; Kebutuhan pemustaka

\begin{abstract}
Abstrak
Tulisan ini sebuah konsep yang bertujuan untuk menjawab beberapa permasalahan yaitu faktor-faktor apa yang menentukan kebutuhan, bagaimana formulasi rasio kebutuhan, bagaimana formulasi rasio kebutuhan pemustaka bagi Sekolah Tinggi Agama Islam Negeri Curup dan bagaimana penyimpangan koleksi terhadap kebutuhan. Jenis penelitian yang digunakan dalam penelitian ini adalah penelitian deskriptif analisis. Populasi penelitian ini adalah sivitas akademika Sekolah Tinggi Agama Islam Negeri Curup tahun 2017. Proses analisis dilakukan dengan meletakkan konsep-konsep
\end{abstract}


deskriptif sehingga menciptakan sebuah rumus yang dapat digunakan untuk mengukur kebutuhan bahan perpustakaan. Faktor-faktor yang mempengaruhi penghitungan kebutuhan pokok pemustaka perpustakaan perguruan tinggi adalah jumlah pemustaka, jumlah judul penunjang setiap mata kuliah, jumlah hari aktif, jumlah pinjaman, lama waktu peminjaman, jumlah fakultas atau jurusan, jumlah program studi dan jumlah mata kuliah. Formulasi menunjukkan jumlah kebutuhan secara minimal dan maksimal. Jumlah minimal bahan perpustakaan STAIN Curup adalah 38.516 judul. Penyimpangan terjadi karena adanya kerusakan koleksi, kehilangan koleksi, koleksi yang sudah out of date, penambahan jumlah pemustaka, perkembangan perguruann tinggi, dan peminjaman bagi karyawan perguruan tinggi yang tidak terhitung sebagai pemustaka perpustakaan. Perpustakaan masih perlu melakukan komunikasi secara baik kepada pemustaka sehingga apa yang dibutuhkan mereka dapat tercatat dan dipenuhi oleh perpustakaan.

Kata Kunci: Pengembangan koleksi; Koleksi perpustakaan; Kebutuhan pemustaka

\section{A. PENDAHULUAN}

\section{Latar Belakang}

Salah satu kegiatan pokok perpustakaan yaitu pembinaan koleksi dimana kegiatan ini terdiri dari kegiatan-kegiatan analisis kebutuhan pemustaka, perancangan kebijakan pengembangan koleksi, proses seleksi, proses pengadaan, proses stock opname, proses weeding atau penyiangan dan proses evaluasi.

Dalam mengukur kebutuhan pemustaka seharusnya menggunakan model pengukuran dengan penghitungan mendetail dan cermat. Proses penghitungan dan pengidentifikasian kebutuhan bahan perpustakaan dilakukan secara berkesinambungan dan terkoordinir dengan pihak-pihak yang terkait. Hal ini dilakukan untuk menentukan langkah mencapai tingkat ketersediaan kebutuhan masyarakat pemustaka.

Sebuah perpustakaan perguruan tinggi akan dikatakan memberikan ketersediaan bahan perpustakaan bagi sivitas akademika atau masyarakat pemustaka jika koleksi yang dimiliki telah memenuhi kebutuhan mereka. Sementara kebutuhan masyarakat pemustaka diukur melalui kebijakan dan aturan-aturan tertentu sehingga akan menjadi besaran kebutuhan masyarakat pemustaka yang akan disediakan.

Pada penyelenggaraan fungsi perpustakaan yang berkaitan dengan penyediaan bahan perpustakaan ini, bagi perpustakaan Sekolah Tinggi 
Agama Islam Negeri (STAIN) Curup belum melakukan penetapan tingkat atau besaran kebutuhan masyarakat pemustaka. Pada penambahan atau pengadaan bahan perpustakaan belum dapat dilihat sejauh mana ketersediaan bahan perpustakaan yang dimiliki oleh perpustakaan.

Penetapan jumlah koleksi perpustakaan perguruan tinggi di Indonesia telah diatur di dalam Peraturan Kepala Perpustakaan Nasional Republik Indonesia Nomor 13 Tahun 2017 tentang Standar Nasional Perpustakaan Perguruan Tinggi. Sekalipun demikian pada penerapannya akan berbeda pada masing-masing perpustakaan perguruan tinggi, hal ini dipengaruhi oleh beberapa faktor antara lain kebijakan pelayanan perpustakaan yang meliputi waktu layanan, banyaknya peminjaman dan lain-lain. Dengan demikian penulis memandang perlu melakukan kajian terhadap pengaruh beberapa faktor penting yang sangat mempengaruhi penghitungan kebutuhan bahan perpustakaan bagi masyarakat pemustaka.

Model formulasi rasio kebutuhan pada penelitian ini adalah bagian dari kegiatan analisis kebutuhan pemustaka. Kegiatan ini menetapkan ukuran kebutuhan pemustaka secara keseluruhan yang akan digapai oleh perpustakaan dengan selalu mengevaluasi perkembangan kebutuhan.

Jenis kebutuhan bahan perpustakaan bagi perpustakaan adalah sesuai dengan jenis bahan perpustakaan dan bentuk pelayanan yang disediakan oleh perpustakaan tersebut. Pada kajian ini, peneliti mengupas formulasi rasio kebutuhan untuk bahan perpustakaan utama yaitu yang menunjang pelayanan sumber daya informasi yang sangat berkaitan dengan kegiatan perkuliahan dan penelitian ilmiah. Adapun bahan perpustakaan yang dimaksud adalah bahan perpustakaan untuk layanan sirkulasi, tandon, referensi dan jurnal. Data yang diperoleh adalah data pada STAIN Curup. Strata pendidikan yang menjadi contoh formulasi rasio kebutuhan bahan perpustakaan yaitu pendidikan strata 1 atau $\mathrm{S} 1$.

Layanan sirkulasi adalah layanan peminjaman koleksi perpustakaan untuk dibawa pulang dan harus dikembalikan dalam waktu tertentu. Layanan tandon adalah layanan koleksi perpustakaan yang hanya dapat dipinjam dan dibaca di tempat layanan. Koleksi pada layanan tandon ini adalah satu judul dari seluruh koleksi yang dimiliki oleh perpustakaan kecuali koleksi referensi. Layanan referensi adalah layanan perpustakaan untuk menggunakan koleksi referensi dan hanya dapat dibaca di tempat layanan. Koleksi pada layanan referensi ini meliputi seluruh bahan perpustakaan yang bersifat referensi seperti kamus, ensiklopedi, kitab-kitab tafsir, dan bahan perpustakaan yang memuat informasi singkat lainnya. Layanan jurnal adalah 
layanan perpustakaan meliputi koleksi jurnal ilmiah, jurnal populer, surat kabar baik cetak maupun elektronik..

Pemustaka yang berasal dari mahasiswa adalah seluruh mahasiswa STAIN Curup dengan rincian sebagai berikut :

Tabel 1. Asal Pemustaka Program Studi STAIN Curup

\begin{tabular}{l|l} 
No. & \multicolumn{1}{|c}{ Program Studi } \\
\hline $\mathbf{1}$ & Program Studi Pendidikan Agama Islam (PAI) \\
\hline $\mathbf{2}$ & Program Studi Tadris Bahasa Inggris (PBI) \\
\hline $\mathbf{3}$ & Program Studi Pendidikan Bahasa Arab(PBA) \\
\hline $\mathbf{4}$ & Program Studi Pendidikan Guru Madrasyah Ibtidaiyyah (PGMI) \\
\hline $\mathbf{5}$ & Program Studi Manajemen Pendidikan Islam (MPI) \\
\hline $\mathbf{6}$ & Program Studi Bimbingan Konseling Islam (BKI) \\
\hline $\mathbf{7}$ & Bimbingan Penyuluhan Islam (BPI) \\
\hline $\mathbf{8}$ & Tadris Matematika (TM) \\
\hline $\mathbf{9}$ & Tadris Bahasa Indonesia (TBI) \\
\hline $\mathbf{1 0}$ & Pendidikan Islam Anak Usia Dini (PIAUD) \\
\hline $\mathbf{1 1}$ & Program Studi Komunikasi dan Penyiaran Islam (KPI) \\
\hline $\mathbf{1 2}$ & Program Studi Ilmu Al-Qur'an dan Tafsir (IQT) \\
\hline $\mathbf{1 3}$ & Prodi Hukum Keluarga Islam (AS) \\
\hline $\mathbf{1 4}$ & Prodi Perbankan Syariah (SE) \\
\hline $\mathbf{1 5}$ & Prodi Ekonomi Syariah (SE) \\
\hline $\mathbf{1 6}$ & Prodi Hukum Tatanegara Islam (HTI)
\end{tabular}

Setiap program studi mengharuskan mahasiswanya menempuh beberapa mata kuliah yang terdiri dari mata kuliah umum atau kategori mata kuliah STAIN, mata kuliah jurusan, dan mata kuliah program studi atau keahlian.

Kompleksitas faktor-faktor yang diuraikan di atas akan menjadikan bahan kajian dalam penelitian ini.

\section{Rumusan Masalah}

Rumusan masalah yang tetapkan pada penelitian ini adalah: faktorfaktor apa yang menentukan kebutuhan, bagaimana formulasi rasio kebutuhan, bagaimana kebutuhan pemustaka bagi Sekolah Tinggi Agama Islam Negeri Curup, dan bagaimana penyimpangan koleksi terhadap kebutuhan. 


\section{Tujuan dan Kegunaan}

Tujuan penelitian ini adalah untuk mengetahui faktor-faktor yang menentukan kebutuhan bahan perpustakaan bagi sebuah perpustakaan perguruan tinggi, untuk mengetahui formulasi rasio kebutuhan yang mungkin terjadi, untuk melihat hasil penghitungan melalui formulasi rasio kebutuhan yang telah dirancang bagi masyarakat pemustaka STAIN Curup, serta mengetahui penyimpangan koleksi yang dimiliki perpustakaan STAIN Curup terhadap kebutuhan.

Adapun kegunaan penelitian ini secara praktis adalah sebagai formulasi rasio kebutuhan yang dapat digunakan perpustakaan untuk melihat tingkat kebutuhan masyarakat pemustaka. Kegunaan teoritis adalah sebagai salah satu rujukan untuk peneliti selanjutnya dalam mengkaji permasalahan yang sama.

Penelitian yang dilakukan dengan judul model formulasi rasio kebutuhan bahan perpustakaan (analisis terhadap kebutuhan bahan perpustakaan Sekolah Tinggi Agama Islam Negeri Curup) ini lebih menekankan pada gambaran jumlah minimal dan maksimal kebutuhan bahan perpustakaan bagi masyarakat pemustaka. Sejauh ini belum ada penelitian khusus tentang formulasi ini.

\section{Tinjauan Pustaka}

Pada pengkajian mengenai model formulasi rasio kebutuhan bahan perpustakaan akan dibicarakan dan dibahas beberapa pengertian operasional model, formulasi, rasio, analisis kebutuhan, dan bahan perpustakaan.

Pengertian model adalah rencana, representasi, atau deskripsi yang menjelaskan suatu objek, sistem, atau konsep, yang seringkali berupa penyederhanaan atau idealisasi. Bentuknya dapat berupa model fisik (maket, bentuk prototipe), model citra (gambar rancangan, citra komputer), atau rumusan matematis. (Wikipedia, 2017)

John Mc Neil (1985) dalam (Rizal, 2012) mendefinisikan need assessment sebagai: "the process by which one defines educational needs and decides what their priorities are".

Pengertian formulasi adalah perumusan. Sedangkan memformulasikan atau adalah merumuskan atau menyusun dalam bentuk yang tepat (Setiawan, Kamus Besar Bahasa Indonesia, 2017).

Pengertian rasio adalah pemikiran menurut akal sehat; akal budi; nalar; berasio berarti mempunyai rasio, berkemampuan menggunakan rasio atau 
akal dengan baik, berkemampuan untuk memahami, menyimpulkan, berpikir secara logis. (Setiawan, 2012)

Banyak pendapat mengenai pengertian bahan bacaan dan bahan perpustakaan. Setiap pengertian mempunyai perspektifnya sendiri. Kedua istilah ini terdiri dari 2 suku kata, yaitu bahan dan bacaan, serta bahan dan pustaka. Dalam Kamus Besar Bahasa Indonesia bahan diartikan segala sesuatu yang dapat dipakai atau diperlukan untuk tujuan tertentu. Sedangkan bacaan memiliki arti buku dan sebagainya yang dibaca. Sedangkan pustaka mempunyai arti buku.

Keputusan Menteri Dalam Negeri dan Otonomi Daerah Nomor 3 tahun 2001 tentang Perpustakaan Desa/kelurahan memberikan pengertian bahan bacaan adalah semua media cetak yang disediakan bagi masyarakat dalam bentuk buku, majalah, tabloit, surat kabar, brosur, leaflet, dan bahan cetakan lainnya yang bersifat informatif yang dapat dibaca, dipelajari dan memberi manfaat bagi kehidupan masyarakat. Sedangkan (Yulia \& Sujana, 2009) menyinggung bahwa perpustakaan memerlukan bahan bacaan atau bahan lain untuk keperluan rekreasi intelektual dan bahan bacaan lain yang memperkaya khazanah pengguna.

Menurut UU Perpustakaan No. 43 Tahun 2007 tentang perpustakaan, memberikan pengertian bahwa bahan perpustakaan atau bahan perpustakaan adalah semua hasil karya tulis, karya cetak, dan/atau karya rekam. Sedangkan menurut (Qasim, 2013) memberikan pengertian bahwa bahan perpustakaan adalah dokumen yang memuat informasi pengetahuan ilmiah dengan tujuan penciptaannya untuk kegiatan kultural dan pendidikan.

Sulistyo-basuki (Sulistyo-Basuki, 1993) memberikan cakupan dari bahan perpustakaan, yaitu : 1) karya cetak atau karya grafis seperti buku, majalah surat kabar, disertasi, laporan. 2) Karya non-cetak atau karya rekam, seperti piringan hitam, rekaman audio, kaset, dan video. 3) Bentuk mikro, seperti microfilm, mikrofis, dan microopaque. 4) Karya dalam bentuk elektronik dan bahan digital lainnya.

Kebutuhan pemustaka adalah seluruh kebutuhan sumber daya informasi yang menunjang kegiatan utama civitas akademika. Bagi mahasiswa dan dosen mereka harus menggunakan sumber daya informasi dalam rangka mengkaji seluruh mata kuliah yang diprogramkan di dalam kurikulum. Bagi karyawan Sekolah Tinggi Agama Islam Negeri (STAIN) Curup, mereka membutuhkan sumber daya informasi yang berkaitan dengan keahlian dan pekerjaan mereka. Bagi para peneliti membutuhkan sumber daya informasi yang berkaitan dengan keilmuan bidang mereka. 
Model formulasi rasio kebutuhan bahan perpustakaan dimaksudkan adalah suatu rancangan kerja perpustakaan secara terukur dan terencana mengenai proses pengembangan kebutuhan pemustaka yang berupa bahan perpustakaan baik yang dipinjamkan, dibawa pulang atau yang hanya dapat dibaca di perpustakaan. Kebutuhan yang sesungguhnya harus dianalisis dengan cermat sehingga proses pengembangan koleksi perpustakaan benarbenar mencerminkan kebutuhan pemustaka.

Kajian tentang bagaimana menentukan kebutuhan bahan perpustakaan bagi masyarakat pemustaka adalah bagian dari kegiatan pengembangan koleksi. Definisi pengembangan koleksi dijelaskan dalam beberapa literatur antara lain sebagai berikut: Library collection development is the process of meeting the information needs of the people (a service population) in a timely and economical manner using information resources locally held, as well as from other organizations (Evan, 2000).

Pengertian Pengembangan Koleksi menurut The ALA Glossary of Library and Information Science yaitu:

A term which encompasses a number of activities related to the development of the library collection, including the determination of the library collection, including the determination and coordination of selection policy, assessment of needs of users and potential users, collection evaluation, identification of collection needs, selection of materials, planning for resource sharing, collection maintenance, and weeding (Young, 1983).

Artinya sejumlah kegiatan yang berkaitan dengan penentuan dan koordinasi kebijakan seleksi, menilai kebutuhan pemakai, studi pemakaian koleksi, evaluasi koleksi, identifikasi kebutuhan koleksi, seleksi bahan perpustakaan, perencanaan kerja sama, pemeliharaan koleksi dan penyiangan koleksi perpustakaan.

Ada beberapa penelitian yang telah dilakukan berkaitan dengan analisis kebutuhan pemustaka antara lain:

Skripsi Saira Solot membahas tentang "Analisis Kebutuhan Pemustaka dan Ketersediaan Koleksi Bahan perpustakaan di Perpustakaan Universitas Indonesia Timur Makassar". Pokok permasalahan dari skripsi ini adalah bagaimana kebutuhan pemustaka di perpustakaan Universitas Indonesia Timur Makassar dan ingin mengetahui bagaimanakah ketersediaan koleksi bahan perpustakaan di perpustakaan Universitas Indonesia Timur Makassar. Tujuan dari penelitian adalah untuk mengetahui seberapa besar 
tingkat ketersediaan koleksi-koleksi perpustakaan sesuai dengan kebutuhan pemustaka di perpustakaan Universitas Indonesia Timur Makassar. Jenis penelitian adalah penelitian deskriptif dengan pendekatan kuantitatif. Metode utama yang digunakan penulis untuk mendapatkan data atau informasi dalam penelitiannya adalah angket, sedangkan metode pendukungnya berupa observasi dan dokumentasi. Populasi dalam penelitian ini adalah mahasiswa yang berada di Perpustakaan Universitas Indonesia Timur Makassar yang berjumlah 200 dan sampel 50 responden di ambil dari 25\% tingkat kesalahan. Penulis menggunakan teknik accidental sampling. uji validasi instrument dilakukan dengan korelasi pearson dan uji reliabilitas instrument menggunakan rumus alpha crombach yang dihitung menggunakan software SPSS for windows version 19. Hasil penelitian ini menggambarkan bahwa analisis kebutuhan pemustaka dan ketersediaan koleksi bahan perpustakaan di perpustakaan Universitas Indonesia Timur Makassar dari segi kebutuhannya, koleksi-koleksi Perpustakaan dibutuhkan. Sedangkan tingkat ketersediaan koleksi-koleksinya belum tersedia di perpustakaan Universitas Indonesia Timur Makassar dan belum memenuhi kebutuhan pemustaka (Solot, 2016).

Artikel Harbo dan Hansen berjudul "Getting to Know Library Users' Needs - Experimental Ways to User-centred Library Innovation" menjelaskan bagaimana 110 pustakawan dan spesialis informasi memperoleh metode antropologi di empat kota dan dalam empat hari, melalui lokakarya yang disusun seperti tur berpemandu melalui pengguna perpustakaan. Metode ini memperkenalkan cara praktis bagi staf perpustakaan untuk mengetahui kebutuhan pengguna mereka terhadap layanan. Tujuan dari artikel ini adalah untuk memberi inspirasi kepada perpustakaan lain untuk gagasan, konsep dan alat konkret untuk mempelajari perilaku pengguna dan menjadi lebih sadar akan kebutuhan pengguna akan layanan. Artikel tersebut berisi deskripsi metode yang disebutkan di atas, pengalaman berharga dari lokakarya, presentasi konsep dan alat konkret, diskusi tentang konsep logika pengguna dan layanan perpustakaan, dan tujuh prinsip untuk inovasi yang berpusat pada manusia dalam kaitannya dengan perpustakaan, daftar singkat studi yang dilakukan oleh pustakawan dan diskusi tentang perspektif lebih lanjut (Harbo \& Hansen, 2012).

Artikel Baner dan Tal yang berjudul "SFX, information needs, the Academic Library, and its User" membahas apakah SFX dapat digunakan tidak hanya sebagai penyelesai tautan, namun juga sebagai alat untuk menilai kebutuhan informasi pengguna. Penelitian ini meninjau kontribusi SFX 
terhadap penilaian kebutuhan informasi di perpustakaan akademis dan manfaatnya bagi pengguna dan perpustakaan (Barner \& Tal, 2012).

Artikel Rufaidah, Maksum dan Suryantini dalam Jurnal Perpustakaan Pertanian Vol. 20, Nomor 2, tahun 2011 bertujuan untuk mengetahui jurnaljurnal ilmiah yang dibutuhkan peneliti dan penyuluh lingkup Badan Litbang Pertanian. Pengkajian dilaksanakan dengan menggunakan metode survei dengan populasi peneliti dan penyuluh lingkup Badan Litbang Pertanian. Sampel ditetapkan secara proporsional. Variabel yang diteliti meliputi karakteristik individu peneliti/penyuluh dan kebutuhan jurnal inti. Untuk menilai jurnal yang sesuai dengan kebutuhan responden, ditetapkan 650 judul jurnal yang dikelompokkan dalam 11 subjek yang diajukan dalam kuesioner. (Rufaidah, Maksum, \& Suryantini, 2011).

Penelitian Casserly yang berjudul "Research in academic library collection management" adalah bentuk penelitian kuantitatif dan kualitatif empiris dan studi kasus yang berkaitan dengan praktik pengelolaan koleksi di perpustakaan akademik yang diterbitkan antara tahun 1990 dan 2007. Topik yang dibahas meliputi ukuran dan pertumbuhan koleksi, biaya material, pengeluaran perpustakaan, anggaran dan penganggaran, kebijakan pengembangan koleksi, koleksi komposisi, organisasi dan kepegawaian untuk pengelolaan koleksi, seleksi, dan evaluasi proses pengembangan koleksi dan pengumpulannya sendiri. Studi ini mengidentifikasi sesuatu yang paling berpengaruh dan berguna dan bidang penelitian yang paling aktif (Casserly, 2008).

Sebuah penelitian Moyo dan Cahoy yang berjudul Meeting the needs of remote library users meneliti persepsi, harapan, dan penggunaan sumber daya perpustakaan berbasis Penn State World Campus. Kampus Universitas Penn State University (kampus virtual) adalah salah satu institusi pendidikan jarak jauh terkemuka di Amerika Serikat. Temuan utama adalah bahwa siswa senang dengan kualitas dan ketersediaan layanan perpustakaan, namun tidak sepenuhnya menikmati beragam layanan dan koleksi (Moyo \& Cahoy, 2003).

Manajemen siklus koleksi adalah cara untuk mengambil pendekatan jangka panjang terhadap penataan layanan yang bertanggung jawab atas koleksi British Library dan merupakan salah satu dari alur strategis perpustakaan. Tulisan ini mendefinisikan berbagai tahap dalam eksistensi barang koleksi seiring berjalannya waktu, mulai dari proses seleksi dan akuisisi, hingga konservasi, penyimpanan dan temu kembali. Manajemen siklus koleksi berusaha untuk mengidentifikasi biaya setiap tahap untuk 
menunjukkan interdependensi ekonomi dari masa ke masa. Dengan demikian, tujuannya untuk menunjukkan konsekuensi jangka panjang dari apa perpustakaan menjadikan koleksi, dengan membuat eksplisit implikasi keuangan dan lainnya. Keputusan dibuat pada awal siklus untuk 100 tahun ke depan. Akhirnya, tulisan ini bertujuan untuk menggabungkan siklus koleksi kertas dan digital, secara berurutan untuk mencerminkan totalitas koleksi hibrida British Library (Shenton, 2003).

Sebuah studi pada pengguna perpustakaan jarak jauh menunjukkan bahwa pengguna lebih menyukai database online dan internet sebagai sumber informasi karena mudah diakses dan mudah digunakan. Namun mereka menggunakan buku dan jurnal, yang merupakan sumber cetak, sebagai sumber informasi utama karena database online dan internet tidak dapat memenuhi kebutuhan informasinya. Selain itu, 86,7 persen pengguna jarak jauh menganggap layanan perpustakaan sebagai isu penting untuk memilih program pembelajaran jarak jauh, dan pengguna jarak jauh sangat termotivasi oleh para profesor mereka untuk menggunakan perpustakaan sehingga perlu ada kemitraan antara program pembelajaran jarak jauh dan layanan perpustakaan. Akhirnya, pengguna jarak jauh menganggap otoritas dan keakuratan dan isi informasi yang diperoleh sebagai isu penting untuk informasi mereka daripada desain database, sehingga perpustakaan harus mengamankan lebih banyak informasi digital untuk kebutuhan pengguna jarak jauh. Penelitian ini bertujuan untuk meningkatkan kualitas layanan informasi bagi pengguna jarak jauh, namun penelitian ini tidak cukup menyeluruh, dan harus ada penelitian perbaikan selanjutnya (Kim, 2000).

Penelitian yang dilakukan sebelumnya adalah menganalisis kebutuhan berdasarkan pemustaka terhadap bahan perpustakaan yang dibutuhkan mereka. Hasil yang didapatkan adalah identifikasi kebutuhan berdasarkan masyarakat pemustaka dan ketersediaan kebutuhan mereka di perpustakaan. Hasil penelitian lain menunjukkan beberapa bahan perpustakaan yang tersedia tidak semuanya digunakan oleh pemustaka dengan demikian pustakawan harus lebih memilih judul-judul bahan perpustakaan yang benarbenar digunakan. Penulis belum menjumpai penelitian yang khusus berkaitan dengan formulasi kebutuhan pemustaka.

\section{Metode Penelitian}

Metode penelitian yang digunakan dalam penulisan ini memuat jenis penelitian, populasi, teknik pengumpulan dan pengolahan data serta waktu dan tempat penelitian. 


\section{Jenis Penelitian}

Jenis penelitian yang digunakan dalam penelitian ini adalah penelitian eksperimen karena penelitian ini akan melihat akibat atau hasil yang ditimbulkan oleh suatu konsep penulis secara sengaja, sebagaimana dijelaskan oleh Hadi (Hadi, 1985), penelitian eksperimen adalah penelitian yang dilakukan untuk mengetahui akibat yang ditimbulkan dari suatu perlakuan yang diberikan secara sengaja oleh peneliti. Definisi lain menyatakan bahwa hakekat penelitian eksperimen adalah meneliti pengaruh perlakuan terhadap perilaku yang timbul akibat perlakuan (Alsa, 2004).

\section{Populasi dan Sampel}

Populasi adalah seluruh data yang menjadi perhatian peneliti dalam suatu ruang lingkup dan waktu yang ditentukan (Zuriah, 2006). Pengertian lain menyatakan bahwa populasi adalah keseluruhan obyek penelitian yang terdiri dari manusia, benda, hewan, tumbuhan, gejala, nilai tes, atau peristiwa sebagai sumber data yang memiliki karakteristik tertentu di dalam suatu penelitian (Nawawi, 1983).

Populasi penelitian ini adalah sivitas akademika Sekolah Tinggi Agama Islam Negeri Curup tahun 2017 sebagai masyarakat yang membutuhkan bahan perpustakaan di perpustakaan. Sampel yang ditetapkan adalah sivitas akademi Sekolah Tinggi Agama Islam Negeri tahun 2017.

\section{Teknik Pengumpulan dan Pengolahan Data}

Data yang dibutuhkan dikumpulkan melalui observasi dan dokumentasi. Seluruh data dikumpulkan dan dianalisis secara kuantitatif berdasarkan formulasi yang ditetapkan dengan logika peneliti.

\section{Waktu dan Tempat Penelitian}

Penelitian ini dilakukan selama satu bulan pada bulan Maret tahun 2017 di Sekolah Tinggi Agama Islam Negeri Curup.

\section{B. HASIL DAN PEMBAHASAN}

Dalam tulisan ini sub pembahasan meliputi faktor-faktor yang menentukan kebutuhan, formulasi rasio kebutuhan, pemaparan data, pengukuran kebutuhan dan penyimpangan koleksi terhadap kebutuhan.

\section{Faktor-Faktor yang Menentukan Kebutuhan}

Faktor-faktor yang mempengaruhi penghitungan kebutuhan pokok pemustaka perpustakaan perguruan tinggi adalah jumlah pemustaka, jumlah judul penunjang setiap mata kuliah, jumlah hari aktif, jumlah pinjaman, lama 
waktu peminjaman, jumlah fakultas atau jurusan, jumlah program studi dan jumlah mata kuliah.

Jumlah pemustaka adalah seluruh pemustaka yang membutuhkan bahan perpustakaan untuk kebutuhan mereka. Pemustaka perpustakaan perguruan tinggi terdiri dari mahasiswa, dosen, profesional dan ahli bidang tertentu. Mahasiswa dan dosen membutuhkan literatur-literatur atau bahan perpustakaan untuk menunjang pengkajian mata kuliah dalam kurikulum mereka. Profesional dan ahli bidang tertentu membutuhkan bahan perpustakaan untuk menunjang pengkajian ilmiah dan data dan informasi penting dalam profesi mereka. Sebagai penghitungan dasar, jumlah pemustaka adalah jumlah kebutuhan, jika jumlah pemustaka 100 maka jumlah kebutuhan mereka adalah 100 untuk setiap judul dalam mata kuliah. Dengan demikian setiap pemustaka memiliki kesempatan menggunakan 1 eksemplar untuk tiap judul bahan perpustakaan. Dengan ketentuan bahwa setiap mata kuliah didukung oleh beberapa judul bahan perpustakaan maka setiap pemustaka memiliki kesempatan menggunakan beberapa judul bahan perpustakaan dalam satu mata kuliah.

Penentuan jumlah pemustaka ini penting terlebih untuk beberapa jenis mata kuliah yang berbeda perlakuannya. Misalnya dalam satu Program Studi terdiri dari 3 jenis mata kuliah yaitu mata kuliah umum atau diambil oleh seluruh mahasiswa perguruan tinggi, mata kuliah Jurusan yaitu mata kuliah yang diambil untuk mahasiswa dalam jurusan tertentu, dan mata kuliah Program Studi yaitu mata kuliah yang diambil hanya untuk mahasiswa Program Studi tertentu.

Jumlah judul penunjang setiap mata kuliah adalah jumlah judul minimal yang ditetapkan oleh pihak perpustakaan, profesional atau dosen dan perguruan tinggi yang tertuang dalam kebijakan pengembangan koleksi perpustakaan. Misalnya untuk mata kuliah filsafat ilmu membutuhkan 25 bahan perpustakaan yang terdiri dari 10 monograf pokok, 10 monograf penunjang, 3 karya referensi, dan 2 jurnal ilmiah. Dengan demikian perpustakaan menyediakan 20 bahan perpustakaan yang dapat dipinjam dibawa pulang dan 5 bahan perpustakaan digunakan di perpustakaan. Masing-masing pemustaka dapat berbagi bahan perpustakaan dari 20 judul yang disediakan.

Jumlah hari aktif adalah jumlah hari dalam satu pelaksanaan pelayanan perpustakaan. Penjadualan pelaksanaan pelayanan perpustakaan biasanya adalah mulai hari Senin hingga hari Sabtu, yaitu selama 6 hari. Dengan 
demikian seluruh pemustaka akan berbagi waktu dalam pemanfaatan bahan perpustakaan sesuai jadual yang ditetapkan.

Jumlah pinjaman adalah banyaknya bahan perpustakaan yang boleh dipinjam dibawa pulang oleh setiap pemustaka. Pemustaka dalam menggunakan bahan perpustakaan tidak cukup hanya 1 eksemplar atau judul saja yang mereka pinjam, akan tetapi setiap pemustaka cenderung membutuhkan lebih dari satu bahan perpustakaan. Banyaknya bahan perpustakaan yang boleh dipinjam diatur dan ditetapkan oleh pihak perpustakaan dan diketahui dan disetujui oleh pimpinan perguruan tinggi. Dengan demikian kebutuhan bahan perpustakaan bagi setiap pemustaka terjadi penambahan sebanyak jumlah bahan perpustakaan yang boleh dipinjam dibawa pulang.

Lama waktu peminjaman adalah lama waktu bahan perpustakaan dapat digunakan oleh pemustaka. Lama waktu peminjaman ini juga harus ditetapkan oleh pihak perpustakaan dan diketahui dan disetujui oleh pimpinan perguruan tinggi. Dengan demikian bahan perpustakaan yang disediakan akan berada di luar perpustakaan selama waktu tersebut, sehingga bagi setiap pemustaka lain membutuhkan ketersediaan bahan perpustakaan lain sejumlah lamanya waktu peminjaman tersebut.

Jumlah fakultas atau jurusan adalah banyaknya fakultas atau jurusan yang ada di perguruan tinggi perpustakaan yang dimaksud.

Jumlah program studi adalah banyaknya program studi yang ada di perguruan tinggi perpustakaan yang dimaksud.

Jumlah mata kuliah adalah jumlah seluruh mata kuliah yang diberikan dalam satu program studi yang terdiri dari 3 kategori mata kuliah yaitu mata kuliah umum atau perguruan tinggi, mata kuliah jurusan, dan mata kuliah program studi atau keahlian.

\section{Formulasi Rasio Kebutuhan}

Berdasarkan uraian faktor-faktor yang menentukan kebutuhan di atas, maka secara formulasi, rasio kebutuhan pokok bahan perpustakaan bagi pemustaka adalah: Untuk 100 pemustaka suatu mata kuliah membutuhkan bahan perpustakaan 100 pula. Jika perpustakaan menyediakan 100 eksemplar bahan perpustakaan, maka setiap pemustaka dapat meminjam bahan perpustakaan masing-masing 1 eksemplar.

Perpustakaan akan memberikan pelayanan peminjaman bahan perpustakaan minimal 1 eksemplar, maka jumlah bahan perpustakaan yang 
harus disediakan oleh perpustakaan adalah 100 eksemplar. Jika perpustakaan memberikan pelayanan peminjaman 4 eksemplar untuk tiap pemustaka maka perpustakaan harus menyediakan 400 eksemplar bahan perpustakaan yang merupakan perkalian dari 100 dan 4.

Perpustakaan akan memberikan pelayanan peminjaman minimal dalam waktu satu hari, maka jumlah eksemplar yang harus disediakan oleh perpustakaan adalah 100 eksemplar (setiap pemustaka hanya boleh meminjam 1 eksemplar). Jika perpustakaan memberikan pelayanan 7 hari masa peminjaman, maka kemungkinan perpustakaan tidak menyimpan bahan perpustakaan selama 7 hari masa peminjaman. Sementara setiap pemustaka berkesempatan meminjam 1 eksemplar untuk tiap hari pelayanan (setiap hari pelayanan pemustaka mengganti peminjaman). Dengan demikian perpustakaan harus menyediakan 100 eksemplar bahan perpustakaan yang digandakan.

Dari seluruh eksemplar bahan perpustakaan yang disediakan oleh perpustakaan, mereka terdiri dari 20 judul misalnya untuk setiap mata kuliah. Dengan demikian jumlah eksemplar untuk tiap judul adalah jumlah total eksemplar dibagi 20 yaitu 5 (100/20). Maka setiap judul disediakan 5 eksemplar. Semakin banyak judul yang ditetapkan maka semakin kecil jumlah eksemplar tiap judul yang harus disediakan.

Jumlah hari aktif pelayanan perpustakaan akan membagikan seluruh pemustaka yang akan dilayani. Misalnya perpustakaan memberikan 6 hari pelayanan, maka jumlah 100 pemustaka dapat dilayani adalah 17 pemustaka per hari (100 pemustaka dibagi 6 hari).

Jumlah eksemplar dan jumlah judul kebutuhan bahan perpustakaan yang dipinjam baca di perpustakaan ditetapkan yang terbesar di antara keduanya. Jika jumlah pemustaka 6000 maka jumlah eksemplar kebutuhan adalah 6000 dibagi dengan lama waktu layanan, jika waktu layanan 6 hari maka jumlah kebutuhan adalah 1000 eksemplar. Jumlah kebutuhan judul adalah seluruh jumlah mata kuliah program studi dikali dengan jumlah program studi ditambah seluruh mata kuliah jurusan dikali dengan jumlah jurusan ditambah seluruh mata kuliah STAIN (umum) dikali dengan 1 (satu) kemudian dikalikan kembali dengan jumlah judul minimal yang ditetapkan (misalnya 20) untuk setiap mata kuliah. Jika mata kuliah prodi adalah 15 dikali 10 (jumlah prodi) adalah 150, mata kuliah jurusan 10 dikali 3 (jumlah jurusan) adalah 30, dan mata kuliah STAIN 10 dikali 1 adalah 10, maka jumlah kebutuhan judul adalah 190 dikali 20 yaitu 3800 judul. Jumlah kebutuhan bahan perpustakaannya adalah 3800 eksemplar atau judul. 
Jumlah fakultas, jurusan, dan program studi menjadi faktor yang menentukan jenis mata kuliah dalam kurikulum. Penentuan jumlah prosentasi mata kuliah berdasarkan kategori tersebut ditetapkan oleh perguruan tinggi. Misalnya satu program studi di STAIN Curup terdiri dari 35 mata kuliah yang terbagi menjadi 10 mata kuliah perguruan tinggi, 10 mata kuliah jurusan, dan 15 mata kuliah program studi atau keahlian. Setiap kategori mata kuliah mempengaruhi jumlah pemustaka. Mata kuliah perguruan tinggi akan lebih banyak pemustakanya karena diikuti oleh seluruh mahasiswa, mata kuliah jurusan pemustakanya adalah yang mengikuti mata kuliah jurusan, sementara mata kuliah program studi pemustakanya lebih kecil karena diikuti hanya bagi mahasiswa program studi pada semester tertentu.

Dari uraian faktor-faktor di atas, kebutuhan pemustaka dapat digambarkan dalam bentuk rumus sebagai berikut:

1. Bahan perpustakaan yang dipinjam dibawa pulang (sirkulasi)

Jika kebutuhan disimbolkan $\mathbf{K}$, pemustaka disimbolkan $\mathbf{P}$, judul bahan perpustakaan yang dipinjamkan disimbolkan $\mathbf{J}$, hari aktif disimbolkan Ha, jumlah eksemplar pinjaman disimbolkan $\mathbf{P j}$, dan lama pinjaman dibawa pulang disimbolkan Wp maka rumus yang didapat untuk kebutuhan setiap mata kuliah adalah:

a. Untuk 100 pemustaka, 1 eksemplar peminjaman, dan 1 hari masa peminjaman, maka rumus yang diperoleh adalah:

$$
\begin{aligned}
& \mathrm{K}=(\mathrm{P})(\mathrm{Pj})(\mathrm{Wp}) \\
& \mathrm{K}=(100)(1)(1) \\
& \mathrm{K}=100 \text { eksemplar }
\end{aligned}
$$

Keterangan: Masing-masing pemustaka akan mendapatkan pinjamannya.

b. Untuk 100 pemustaka, 2 eksemplar peminjaman, dan 1 hari masa peminjaman, maka rumus yang diperoleh adalah:

$$
\begin{aligned}
\mathrm{K} & =(100)(2)(1) \\
\mathrm{K} & =200 \text { eksemplar }
\end{aligned}
$$

Keterangan: seandainya perpustakaan menyediakan 100 eksemplar, maka ada pemustaka yang tidak dapat meminjam bahan perpustakaan. 
c. Untuk 100 pemustaka, 1 eksemplar peminjaman, dan 2 hari masa peminjaman, maka rumus yang diperoleh adalah:

$$
\begin{aligned}
& \mathrm{K}=(100)(1)(2) \\
& \mathrm{K}=200 \text { eksemplar }
\end{aligned}
$$

Keterangan:

- Bahan perpustakaan akan berada pada pemustaka selama 2 hari, maka ada kekosongan bahan perpustakaan 1 hari jika semua pemustaka menggunakan hak pinjamnya. Oleh karena itu perpustakaan harus menyediakan 2 kali eksemplar.

- Jika masa peminjaman 3 atau 4 atau 5 hari, perpustakaan cukup menggandakan eksemplar dengan minimal 2 karena sudah dapat memberikan pelayanan. Hal ini dimaksudkan untuk efisiensi biaya.

d. Untuk 100 pemustaka, 2 eksemplar peminjaman, dan 2 hari masa peminjaman, maka rumus yang diperoleh adalah:

$$
\begin{aligned}
& \mathrm{K}=(100)(2)(2) \\
& \mathrm{K}=400 \text { eksemplar }
\end{aligned}
$$

e. Untuk 100 pemustaka, 1 eksemplar peminjaman, dan 1 hari masa peminjaman, akan tetapi dari 100 eksemplar bahan perpustakaan terdiri dari 20 judul, maka rumus yang diperoleh adalah:

$$
\begin{aligned}
K & =\frac{(P)(P j)(W p)}{(J)} \\
K & =\frac{(100)(1)(1)}{(20)} \\
K & =5 \text { eksemplar/judul }
\end{aligned}
$$

Keterangan:

- Untuk setiap judul, perpustakaan menyediakan 5 eksemplar.

- Jumlah judul dalam menunjang satu mata kuliah bergantung pada jenis mata kuliah dan kebijakan perpustakaan.

Untuk kasus jumlah pemustaka yang lebih besar, maka jumlah hari aktif dapat digunakan untuk membagi penyediaan kebutuhan. 
Hal ini karena jumlah hari aktif dapat memperkecil jumlah pemustaka yang dilayani.

$$
\begin{aligned}
K & =\frac{(\mathrm{P})(\mathrm{Pj})(\mathrm{Wp})}{(\mathrm{Ha})} \\
\mathrm{K} & =\frac{(1000)(1)(1)}{(6)} \\
\mathrm{K} & =\frac{1000}{6} \\
\mathrm{~K} & =167 \text { eksemplar }
\end{aligned}
$$

f. Untuk kasus jumlah pemustaka yang lebih besar, untuk 1000 pemustaka, 1 eksemplar peminjaman, dan 1 hari masa peminjaman, jumlah judul bahan perpustakaan terdiri dari 20 judul, hasilnya dibagi dengan jumlah hari aktif pelayanan yaitu 6 , maka rumus yang diperoleh adalah:

$$
\begin{aligned}
\mathrm{K} & =\frac{(\mathrm{P})(\mathrm{Pj})(\mathrm{Wp})}{(\mathrm{J})(\mathrm{Ha})} \\
\mathrm{K} & =\frac{(1000)(1)(1)}{(20)(6)} \\
\mathrm{K} & =\frac{1000}{120} \\
\mathrm{~K} & =8 \text { eksemplar/judul }
\end{aligned}
$$

2. Bahan perpustakaan yang dipinjam dibaca di Perpustakaan

Jika jumlah mata kuliah STAIN disimbolkan MK1, jumlah mata kuliah jurusan disimbolkan MK2, jumlah mata kuliah prodi disimbolkan MK3, jumlah jurusan JUR, jumlah prodi PRO. Maka rumus yang didapat adalah:

g. Untuk pelayanan bahan perpustakaan yang dipinjam baca di perpustakaan. Misalnya layanan tandon jumlah pemustaka adalah 6000, waktu layanan 6 hari, jumlah mata kuliah STAIN adalah 10, jumlah mata kuliah jurusan adalah 10, jumlah mata kuliah prodi adalah 15 , jumlah jurusan adalah 3 , jumlah prodi adalah 10 , 
jumlah judul tiap mata kuliah ditetapkan sama yaitu 20, maka rumus yang diperoleh adalah:

$$
\begin{aligned}
& \mathrm{K}=\frac{\mathrm{P}}{\mathrm{Ha}} \\
& \mathrm{K}=\frac{6000}{6} \\
& \mathrm{~K}=1000 \text { eksemplar } \\
& \mathrm{K}=(\mathrm{MK} 1+\mathrm{MK} 2 * \mathrm{JUR}+\mathrm{MK} 3 * \mathrm{PRO})(20) \\
& \mathrm{K}=\left(10+10^{*} 3+15 * 10\right)(20) \\
& \mathrm{K}=(10+30+150)(20) \\
& \mathrm{K}=(190)(20) \\
& \mathrm{K}=3800 \text { judul } \\
& \mathrm{K}=3800 \text { eksemplar atau judul }
\end{aligned}
$$

h. Untuk kasus layanan referensi dengan jumlah judul 5 tiap maka kuliah akan menjadi sebagai berikut:

$$
\begin{aligned}
\mathrm{K} & =\frac{\mathrm{P}}{\mathrm{Ha}} \\
\mathrm{K} & =\frac{6000}{6} \\
\mathrm{~K} & =1000 \text { eksemplar } \\
\mathrm{K} & =(\mathrm{MK} 1+\mathrm{MK} 2 * \mathrm{JUR}+\mathrm{MK} 3 * \mathrm{PRO})(5) \\
\mathrm{K} & =(10+10 * 3+15 * 10)(5) \\
\mathrm{K} & =(10+30+150)(5) \\
\mathrm{K} & =(190)(5) \\
\mathrm{K} & =950 \text { judul }
\end{aligned}
$$




$$
\mathrm{K}=1000 \text { eksemplar atau judul }
$$

i. Untuk bahan perpustakaan serial bentuk jurnal, jika jumlah program studi yang ada di perguruan tinggi tersebut 15 dan kebijakan menetapkan bahwa setiap program studi minimal menyediakan 2 judul jurnal maka bentuk rumus yang didapat adalah:

$$
\begin{aligned}
\mathrm{K} & =(\mathrm{PRO})(2) \\
\mathrm{K} & =(15)(2) \\
\mathrm{K} & =30 \text { judul }
\end{aligned}
$$

\section{Pemaparan Data}

Data yang ada dalam kaitannya dengan kajian model formulasi rasio kebutuhan bahan perpustakaan yaitu data program studi yang dilaksanakan di STAIN Curup, jenis dan jumlah mata kuliah yang diprogramkan untuk setiap program studi, jumlah mahasiswa sebagai pemustaka untuk tiap mata kuliah, jumlah pemustaka selain mahasiswa, peraturan pelayanan untuk pemustaka di perpustakaan STAIN Curup, serta kebijakan tentang jumlah judul literatur pendukung setiap mata kuliah.

Program studi yang diselenggarakan di STAIN Curup berdasarkan informasi pada website: http://staincurup.ac.id/ adalah jurusan terdiri dari 3 yaitu Jurusan Tarbiyah, Jurusan Dakwah, Komunikasi dan Ushuluddin, Dan Jurusan Syariah dan Ekonomi Islam.

Pada jurusan Tarbiyah terdapat 10 prodi yaitu Program Studi Pendidikan Agama Islam (PAI), Program Studi Tadris Bahasa Inggris (PBI), Program Studi Pendidikan Bahasa Arab(PBA), Program Studi Pendidikan Guru Madrasyah Ibtidaiyyah (PGMI), Program Studi Manajemen Pendidikan Islam (MPI), Program Studi Bimbingan Konseling Islam (BKI), Bimbingan Penyuluhan Islam (Program S-1), Tadris Matematika (Program S-1), Tadris Bahasa Indonesia (Program S-1), Pendidikan Islam Anak Usia Dini (Program S-1).

Pada jurusan Dakwah, Komunikasi dan Ushuluddin terdapat 2 prodi yaitu Program Studi Komunikasi dan Penyiaran Islam (KPI), dan Program Studi Ilmu Al-Qur'an dan Tafsir (IQT). 
Pada jurusan Syariah dan Ekonomi Islam terdapat 4 prodi yaitu Prodi Hukum Keluarga Islam (AS), Prodi Perbankan Syariah (SE), Prodi Ekonomi Syariah (SE), dan Prodi Hukum Tatanegara Islam (HTI).

Prosentase jenis mata kuliah untuk tiap prodi disamakan dengan contoh pada prodi PGMI yaitu 22 mata kuliah STAIN, 18 mata kuliah Jurusan, dan 46 mata kuliah Prodi lihat (http://pgmi.staincurup.ac.id/wpcontent/uploads/2015/12/kurikulum11.jpg).

Jumlah mahasiswa STAIN Curup setiap tahun angkatan kurang lebih 1000 mahasiswa dan setiap lokal mahasiswa rata-rata berjumlah 60 mahasiswa.

Selain mahasiswa, pemustaka perpustakaan STAIN Curup adalah dosen, peneliti dan karyawan. Setiap mata kuliah rata-rata diampu oleh 1 dosen.

Peraturan pelayanan sirkulasi perpustakaan STAIN Curup sesuai dengan tabel layanan pinjaman perpustakaan STAIN Curup adalah:

\begin{tabular}{l|l|l} 
No. & Jenis Pemustaka & Layanan Pinjaman \\
\hline 1. & Mahasiswa Kuliah & 2 eksemplar untuk 7 hari \\
\hline 2. & Mahasiswa Rekomendasi & 4 eksemplar untuk 14 hari \\
\hline 3. & Dosen & 10 eksemplar untuk 160 hari \\
\hline $\mathbf{4 .}$ & Dosen Luar Biasa & 5 eksemplar untuk 30 hari \\
\hline $\mathbf{5 .}$ & Karyawan & 5 eksemplar untuk 10 hari \\
\hline 6. & Mahasiswa pasca & 4 eksemplar untuk 7 hari
\end{tabular}

\section{Pengukuran Kebutuhan}

I. Bahan perpustakaan sirkulasi

1. Jenis mata kuliah STAIN (MK1)

\begin{tabular}{l|l|r|r|r|r|r|r|r|r} 
No. & \multicolumn{1}{|c|}{$\begin{array}{l}\text { Jenis } \\
\text { Pemustaka }\end{array}$} & MK1 & $\mathbf{P}$ & $\mathbf{W p}$ & $\mathbf{P j}$ & $\mathbf{J}$ & $\mathbf{H a}$ & \multicolumn{2}{|c}{ Kebutuhan } \\
\cline { 5 - 9 } & & & & & & & Minimal & Maksimal \\
\hline 1. & $\begin{array}{l}\text { Mahasiswa } \\
\text { Kuliah }\end{array}$ & 22 & 1000 & 7 & 2 & 40 & 6 & 3667 & 308000 \\
\hline 2. & Rekomendasi & 22 & 480 & 14 & 4 & 40 & 6 & 1760 & 591360 \\
\hline 3. & Dosen & 22 & 1 & 160 & 10 & 40 & 6 & 4 & 35200
\end{tabular}




\begin{tabular}{l|l|r|r|r|r|r|r|r|r} 
4. & DLB & 22 & 1 & 30 & 5 & 40 & 6 & 4 & 3300 \\
\hline 5. & Karyawan & 22 & 1 & 10 & 5 & 40 & 6 & 4 & 1100 \\
\hline Jumlah Eksemplar \\
Jumlah Judul \\
Jumlah Eksemplar setiap judul
\end{tabular}

Keterangan:

- $\quad \mathrm{P}=1000$ adalah jumlah mahasiswa baru tiap tahun;

- $\quad P=480$ adalah jumlah mahasiswa akhir materi 30 X 16 (jumlah Prodi);

- $\quad \mathrm{P}=1$ adalah dosen dan DLB pengampu setiap mata kuliah, dan alokasi bahan perpustakaan untuk setiap karyawan.

2. Jenis mata kuliah Jurusan (MK2)

\begin{tabular}{|c|c|c|c|c|c|c|c|c|c|c|}
\hline \multirow[t]{2}{*}{ No. } & \multirow{2}{*}{$\begin{array}{c}\text { Jenis } \\
\text { Pemustaka }\end{array}$} & \multirow{2}{*}{$\begin{array}{c}\text { MK } \\
2\end{array}$} & \multirow[t]{2}{*}{ JUR } & \multirow[t]{2}{*}{$\mathbf{P}$} & \multirow[t]{2}{*}{ Wp } & \multirow[t]{2}{*}{$\mathbf{P j}$} & \multirow[t]{2}{*}{$\mathbf{J}$} & \multirow[t]{2}{*}{ Ha } & \multicolumn{2}{|c|}{ Kebutuhan } \\
\hline & & & & & & & & & Minimal & Maksimal \\
\hline 1. & $\begin{array}{l}\text { Mahasiswa } \\
\text { Kuliah }\end{array}$ & 18 & 3 & 180 & 7 & 2 & 30 & 6 & 1620 & 136080 \\
\hline 2. & Rekomendasi & 18 & 3 & 90 & 14 & 2 & 30 & 6 & 810 & 136080 \\
\hline 3. & Dosen & 18 & 3 & 1 & 160 & 10 & 30 & 6 & 9 & 86400 \\
\hline 4. & DLB & 18 & 3 & 1 & 30 & 5 & 30 & 6 & 9 & 8100 \\
\hline 5. & Karyawan & 18 & 3 & 1 & 10 & 5 & 30 & 6 & 9 & 2700 \\
\hline \multicolumn{9}{|c|}{ Jumlah eksemplar } & 2457 & 369360 \\
\hline \multicolumn{9}{|c|}{ Jumlah judul } & 1620 & 1620 \\
\hline \multicolumn{9}{|c|}{ Jumlah eksemplar setiap judul } & 2 & 228 \\
\hline
\end{tabular}

3. Jenis mata kuliah Prodi (MK3)

\begin{tabular}{|c|c|c|c|c|c|c|c|c|c|c|}
\hline \multirow[t]{2}{*}{ No. } & \multirow{2}{*}{$\begin{array}{c}\text { Jenis } \\
\text { Pemustaka }\end{array}$} & \multirow{2}{*}{$\begin{array}{c}\text { MK } \\
\mathbf{3}\end{array}$} & \multirow[t]{2}{*}{ PRO } & \multirow[t]{2}{*}{$\mathbf{P}$} & \multirow[t]{2}{*}{ Wp } & \multirow[t]{2}{*}{$\mathbf{P j}$} & \multirow[t]{2}{*}{$\mathbf{J}$} & \multirow[t]{2}{*}{ Ha } & \multicolumn{2}{|c|}{ Kebutuhan } \\
\hline & & & & & & & & & Minimal & Maksimal \\
\hline 1. & $\begin{array}{l}\text { Mahasiswa } \\
\text { Kuliah }\end{array}$ & 46 & 16 & 60 & 7 & 2 & 20 & 6 & 7360 & 618240 \\
\hline 2. & Rekomendasi & 46 & 16 & 30 & 14 & 2 & 20 & 6 & 3680 & 618240 \\
\hline 3. & Dosen & 46 & 16 & 1 & 160 & 10 & 20 & 6 & 123 & 1177600 \\
\hline
\end{tabular}


130 | Misroni dan Rahmat Iswanto: Konsep Model Formulasi ..

\begin{tabular}{l|l|r|r|r|r|r|r|r|r|r} 
4. & DLB & 46 & 16 & 1 & 30 & 5 & 20 & 6 & 123 & 110400 \\
\hline 5. & Karyawan & 46 & 16 & 1 & 10 & 5 & 20 & 6 & 123 & 36800 \\
\hline Jumlah Eksemplar \\
Jumlah Judul \\
Jumlah Eksemplar setiap judul
\end{tabular}

II. Bahan perpustakaan referensi

1. Jenis mata kuliah STAIN

\begin{tabular}{l|l|r|r|r|r|r|r} 
No. & Jenis Pemustaka & MK1 & P & J & Ha & \multicolumn{2}{|c}{ Kebutuhan } \\
\cline { 5 - 8 } & & & & & & Minimal & Maksimal \\
\hline $\mathbf{1 .}$ & Mahasiswa Kuliah & 22 & 1000 & 5 & 6 & 167 & 1000 \\
\hline $\mathbf{2 .}$ & Rekomendasi & 22 & 480 & 5 & 6 & 80 & 480 \\
\hline 3. & Dosen & 22 & 1 & 5 & 6 & 1 & 1 \\
\hline $\mathbf{4 .}$ & DLB & 22 & 1 & 5 & 6 & 1 & 1 \\
\hline $\mathbf{5 .}$ & Karyawan & 22 & 1 & 5 & 6 & 1 & 1 \\
\hline Jumlah Eksemplar & & & & & 250 & 1483 \\
\hline Jumlah Judul & & & & 110 & 110 \\
\hline
\end{tabular}

2. Jenis mata kuliah Jurusan

\begin{tabular}{l|l|r|r|r|r|r|r|r} 
No. & Jenis Pemustaka & MK2 & JUR & P & J & Ha & \multicolumn{2}{|c}{ Kebutuhan } \\
\cline { 5 - 9 } & & & & & & Minimal & \multicolumn{1}{|c}{ Maksimal } \\
\hline 1. & Mahasiswa Kuliah & 18 & 3 & 180 & 5 & 6 & 90 & 540 \\
\hline $\mathbf{2 .}$ & Rekomendasi & 18 & 3 & 90 & 5 & 6 & 45 & 270 \\
\hline 3. & Dosen & 18 & 3 & 1 & 5 & 6 & 1 & 3 \\
\hline $\mathbf{4 .}$ & DLB & 18 & 3 & 1 & 5 & 6 & 1 & 3 \\
\hline 5. & Karyawan & 18 & 3 & 1 & 5 & 6 & 1 & 3 \\
\hline Jumlah Eksemplar & & & & & & 137 & 819 \\
\hline
\end{tabular}


3. Jenis mata kuliah Prodi (MK3)

\begin{tabular}{l|l|r|r|r|r|r|r|r} 
No. & Jenis Pemustaka & MK3 & PRO & P & J & Ha & \multicolumn{2}{|c}{ Kebutuhan } \\
\cline { 5 - 9 } & & & & & & Minimal & \multicolumn{1}{l}{ Maksimal } \\
\hline 1. & Mahasiswa Kuliah & 46 & 16 & 60 & 5 & 6 & 160 & 960 \\
\hline $\mathbf{2 .}$ & Rekomendasi & 46 & 16 & 30 & 5 & 6 & 80 & 480 \\
\hline 3. & Dosen & 46 & 16 & 1 & 5 & 6 & 3 & 16 \\
\hline $\mathbf{4 .}$ & DLB & 46 & 16 & 1 & 5 & 6 & 3 & 16 \\
\hline 5. & Karyawan & 46 & 16 & 1 & 5 & 6 & 3 & 16 \\
\hline Jumlah Eksemplar & & & & & & 248 & 1488 \\
\hline
\end{tabular}

III. Bahan perpustakaan tandon

1. Jenis mata kuliah STAIN (MK1)

\begin{tabular}{l|l|r|r|r|r|r|r} 
No. & Jenis Pemustaka & MK1 & P & J & Ha & \multicolumn{2}{|c}{ Kebutuhan } \\
\cline { 5 - 8 } & & & & & & Minimal & Maksimal \\
\hline 1. & Mahasiswa Kuliah & 22 & 1000 & 40 & 6 & 167 & 1000 \\
\hline $\mathbf{2 .}$ & Rekomendasi & 22 & 480 & 40 & 6 & 80 & 480 \\
\hline 3. & Dosen & 22 & 1 & 40 & 6 & 1 & 1 \\
\hline 4. & DLB & 22 & 1 & 40 & 6 & 1 & 1 \\
\hline 5. & Karyawan & 22 & 1 & 40 & 6 & 1 & 1 \\
\hline Jumlah Eksemplar & & & & & 250 & 1483 \\
\hline Jumlah Judul \\
Jumlah Eksemplar setiap judul
\end{tabular}

2. Jenis mata kuliah Jurusan (MK2)

\begin{tabular}{l|l|c|c|c|c|c|r|r} 
No. & Jenis Pemustaka & MK2 & JUR & P & J & Ha & \multicolumn{2}{|c}{ Kebutuhan } \\
\cline { 6 - 8 } & & & & & & & Minimal & \multicolumn{1}{|c}{ Maksimal } \\
\hline 1. & Mahasiswa Kuliah & 18 & 3 & 180 & 30 & 6 & 90 & 540 \\
\hline 2. & Rekomendasi & 18 & 3 & 90 & 30 & 6 & 45 & 270
\end{tabular}


132 | Misroni dan Rahmat Iswanto: Konsep Model Formulasi ..

\begin{tabular}{l|l|r|r|r|r|r|r|r} 
3. & Dosen & 18 & 3 & 1 & 30 & 6 & 1 & 3 \\
\hline 4. & DLB & 18 & 3 & 1 & 30 & 6 & 1 & 3 \\
\hline 5. & Karyawan & 18 & 3 & 1 & 30 & 6 & 1 & 3 \\
\hline Jumlah Eksemplar & & 137 & 819 \\
\hline Jumlah Judul & & 1620 & 1620 \\
\hline
\end{tabular}

3. Jenis mata kuliah Prodi (MK3)

\begin{tabular}{l|l|r|r|r|r|r|r|r} 
No. & Jenis Pemustaka & MK3 & PRO & P & J & Ha & \multicolumn{2}{|c}{ Kebutuhan } \\
\cline { 5 - 9 } & & & & & & Minimal & \multicolumn{1}{|c}{ Maksimal } \\
\hline 1. & Mahasiswa Kuliah & 46 & 16 & 60 & 20 & 6 & 160 & 960 \\
\hline $\mathbf{2 .}$ & Rekomendasi & 46 & 16 & 30 & 20 & 6 & 80 & 480 \\
\hline 3. & Dosen & 46 & 16 & 1 & 20 & 6 & 3 & 16 \\
\hline 4. & DLB & 46 & 16 & 1 & 20 & 6 & 3 & 16 \\
\hline 5. & Karyawan & 46 & 16 & 1 & 20 & 6 & 3 & 16 \\
\hline Jumlah Eksemplar & & & & & & 248 & 1488 \\
\hline
\end{tabular}

IV. Bahan perpustakaan serial bentuk jurnal

\begin{tabular}{l|l|r|r|r|r}
\multirow{2}{*}{ No. } & Jenis Serial & \multirow{2}{*}{ PRO } & \multirow{2}{*}{ J } & \multicolumn{2}{|c}{ Kebutuhan } \\
\cline { 3 - 5 } & & & & Minimal & Maksimal \\
\hline 1. & Jurnal & 16 & 3 & 16 & 48 \\
\hline Jumlah Eksemplar & 16 & 48 \\
\hline Jumlah Judul & 16 & 48 \\
\hline Jumlah Eksemplar setiap judul & 1 & 1
\end{tabular}

Keterangan: jumlah judul setiap jurnal Prodi (misalnya 3) ditetapkan perguruan tinggi. 
V. Ringkasan kebutuhan bahan perpustakaan

\begin{tabular}{|c|c|c|c|c|c|c|c|}
\hline \multirow[t]{3}{*}{ No. } & \multirow{3}{*}{$\begin{array}{c}\text { Alokasi Bahan } \\
\text { perpustakaan }\end{array}$} & \multicolumn{6}{|c|}{ Kebutuhan } \\
\hline & & \multicolumn{3}{|c|}{ Minimal } & \multicolumn{3}{|c|}{ Maksimal } \\
\hline & & Eks. & Jdl. & $\begin{array}{c}\text { Eks/ } \\
\text { Jdl }\end{array}$ & Eks. & Jdl. & $\begin{array}{c}\text { Eks/ } \\
\text { Jdl }\end{array}$ \\
\hline \multirow[t]{4}{*}{1.} & Sirkulasi & & & & & & \\
\hline & - MK1 & 5438 & 880 & 6 & 938960 & 880 & 1067 \\
\hline & - MK2 & 2457 & 1620 & 2 & 369360 & 1620 & 228 \\
\hline & - MK3 & 11408 & 14720 & 1 & 2561280 & 14720 & 174 \\
\hline \multirow[t]{4}{*}{2.} & Referensi & & & & & & \\
\hline & - MK1 & 250 & 110 & 2 & 1483 & 110 & 13 \\
\hline & - MK2 & 137 & 270 & 1 & 819 & 270 & 3 \\
\hline & - MK3 & 248 & 3680 & 1 & 1488 & 3680 & 1 \\
\hline \multirow[t]{4}{*}{3.} & Tandon & & & & & & \\
\hline & - MK1 & 250 & 880 & 1 & 1483 & 880 & 2 \\
\hline & - MK2 & 137 & 1620 & 1 & 819 & 1620 & 1 \\
\hline & - MK3 & 248 & 14720 & 1 & 1488 & 14720 & 1 \\
\hline 4. & Jurnal & 16 & 16 & 1 & 48 & 48 & 1 \\
\hline
\end{tabular}

\section{Penyimpangan Koleksi terhadap Kebutuhan}

Penyimpangan yang terjadi pada penghitungan kebutuhan bahan perpustakaan bagi masyarakat pemustaka disebabkan beberapa hal yaitu koleksi yang disimpan tidak mencerminkan kebutuhan sesungguhnya, adanya kerusakan koleksi, kehilangan koleksi, koleksi yang sudah out of date, penambahan jumlah pemustaka, perkembangan perguruan tinggi, dan peminjaman bagi karyawan perguruan tinggi yang tidak terhitung sebagai pemustaka perpustakaan.

\section{KESIMPULAN}

Setelah faktor-faktor yang mempengaruhi kebutuhan dan formulasi ditentukan, maka kesimpulan yang diperoleh adalah bahwa kebutuhan bahan perpustakaan pada layanan sirkulasi perpustakaan STAIN Curup hingga tahun 2017 minimal adalah 19.303 eksemplar bahan perpustakaan dan 17.220 
judul. Kebutuhan bahan perpustakaan pada layanan referensi perpustakaan STAIN Curup hingga tahun 2017 minimal adalah 4.060 judul atau eksemplar, kebutuhan bahan perpustakaan pada layanan tandon perpustakaan STAIN Curup hingga tahun 2017 minimal adalah 17.120 judul atau eksemplar, dan kebutuhan bahan perpustakaan pada layanan jurnal perpustakaan STAIN Curup hingga tahun 2017 minimal adalah 16 judul atau eksemplar. Meskipun demikian masih dijumpai penyimpangan yang disebabkan beberapa hal. Oleh karena itu diperlukan komunikasi secara baik antara pemustaka dan perpustakaan, sehingga apa yang dibutuhkan dapat dipenuhi oleh perpustakaan.

\section{DAFTAR RUJUKAN}

Alsa, A. (2004). Pendekatan kuantitatif kualitatif dalam penelitian psikologi. Yogyakarta: Pustaka Pelajar.

Barner, K., \& Tal, S. (2012, 6 12). SFX, information needs, the Academic Library, and its User. Library Philosophy and Practice, hal. 754.

Casserly, M. F. (2008). Research in Academic Library Collection Management. University Libraries Fakulty Scholarship, hal. 82-137.

Evan, G. E. (2000). Developing library and information center collection. Westport: Greenwood of Publishing.

Hadi, S. (1985). Metodologi research jilid 4. Yogyakarta: Yayasan Penerbit Fakultas Psikologi UGM.

Harbo, K., \& Hansen, T. V. (2012, 4 11). Getting to know library users' needs experimental ways to user-centred library innovation. LIBER Quarterly, hal. 367-385.

Kim, M. (2000). A Study on the Remote Library Users: Needs of Library Services and Preferences. College of William and Mary, hal. 61-76.

Mardalis. (2008). Metode penelitian suatu pendekatan proposal. Jakarta: Bumi Aksara.

Moyo, L. M., \& Cahoy, E. S. (2003, 7 6). Meeting the needs of remote library users. Library Management, hal. 281-290.

Nawawi, H. (1983). Metode penelitian bidang sosial. Yogyakarta: Gadjah Mada University Press.

Qasim, M. (2013, Mei 9). Pengantar Kearsipan. Dipetik Februari 24, 2017, dari Badan Perpustakaan dan Arsip Daerah Istimewa Yogyakarta: http://bpadjogja.info/file/1d938b00eb7dff2f6d201167affc9b36.pdf.

Rizal, A. (2012, Agustus 22). Merancang Analisis Kebutuhan. Dipetik Februari 24, 2017, dari Slide Share: https://www.slideshare.net/andyrizal/merancanganalisis-kebutuhan 
Rufaidah, V. W., Maksum, \& Suryantini, H. (2011, September 5). Analisis kebutuhan jurnal inti (Core Journal) Peneliti Badan Litbang Pertanian. Jurnal Perpustakaan Pertanian, hal. 70-77.

Setiawan, E. (2012). Rasio. Dipetik Februari 24, 2017, dari Kamus Besar Bahasa Indonesia: http://kbbi.web.id/rasio

Setiawan, E. (2017). Dipetik 2 23, 2018, dari Kamus Besar Bahasa Indonesia: https://kbbi.web.id/formulasi

Shenton, H. (2003). Life Cycle Collection Management. Liber Quarterly, hal. 254272.

Solot, S. (2016). Analisis kebutuhan pemustaka dan ketersediaan koleksi bahan pustaka di perpustakaan Universitas Indonesia Timur. Makasar: Fakultas Adab dan Humaniora UIN Alauddin.

Sulistyo-Basuki. (1993). Pengantar Ilmu Perpustakaan. Jakarta: Gramedia Pustaka Utama.

Tal, K. B. (2012, 6 12). SFX, information needs, the Academic Library, and its User. Library Philosophy and Practice, hal. 754.

Wikipedia. (2015, Maret 25). Formulasi. Dipetik Februari 24, 2017, dari Wikipedia: https://ms.wikipedia.org/wiki/Formulasi

Wikipedia. (2017, April 20). Model. Dipetik Mei 7, 2017, dari Wikipedia: https://id.wikipedia.org/wiki/Model

Young, H. (1983). The ALA glossary of library and information science. Chicago: American Library Association.

Yulia, Y., \& Sujana, J. G. (2009). Pengembangan Koleksi. Jakarta: Universitas Terbuka.

Zuriah, N. (2006). Metodologi penelitian sosial dan pendidikan: teori dan aplikasi. Jakarta: Bumi Aksara.

Peraturan Kepala Perpustakaan Nasional Republik Indonesia Nomor 13 Tahun 2017 Tentang Standar Nasional Perpustakaan Perguruan Tinggi

Peraturan Pemerintah Republik Indonesia Nomor 24 Tahun 2014 Tentang Pelaksanaan Undang-Undang Nomor 43 Tahun 2007 Tentang Perpustakaan

Undang-Undang Republik Indonesia Nomor 43 Tahun 2007 Tentang Perpustakaan 